\title{
Astronomy, culture and landscape in the Early Iron Age in the Ebro Basin
}

\author{
Manuel Pérez Gutiérrez ${ }^{1}$, Jordi Diloli Fons ${ }^{2}$, David Bea Castaño ${ }^{2}$ \\ and Samuel Sardà Seuma ${ }^{2}$ \\ ${ }^{1}$ Higher Polytechnical School of Ávila, University of Salamanca, \\ C/ Hornos Caleros 50, 05003 Ávila, Spain \\ email: manolope@usal.es \\ ${ }^{2}$ Research Group of the Seminar of Protohistory and Archaeology, \\ Universitat Rovira i Virgili, Av. Catalunya 35, 43002 Tarragona, Spain \\ email: david.bea@urv.cat, jordi.diloli@urv.cat, samuel.sarda@urv.cat
}

\begin{abstract}
Archaeological excavations carried out at Turó del Calvari (Tarragona, Spain) have revealed a protohistoric building interpreted as one of the earliest enclosures of power operating during the Early Iron Age in the northeast of the Iberian Peninsula. The structure is exceptional in several respects: the techniques of construction, the materials used, and the topographic situation. The building is perfectly integrated in the landscape and has an exquisite geometrical design, with measurement units based on the Iberian foot. The intended beauty in having used the golden ratio in its construction and an orientation that is both stellar and solar demonstrates the existence at that time of a complete series of mechanisms of representation and territorial control. This was based on the use of rituals and feasts as elements of political cohesion by an emergent elite within a process that reproduced a scaled-down Mediterranean cultural system in an indigenous space.
\end{abstract}

Keywords. archaeoastronomy, calendars, power, cult places, landscape, wine, commensality, feasts

\section{The settlement of the Terra Alta during the Early Iron Age (650-550 BC): a crossroads and place of cultural convergence}

In the early first millennium BC, a profound cultural change took place in the areas known today as Terra Alta and Matarraña (Fig. 1). During the Early Iron Age this was a vast territory inhabited by many local communities that had become established in different settlement areas around the region. That change has been verified by archaeology, with the discovery of the first burial mounds and the application of a new type of population model for the central settlement. The latter includes Roquizal del Rullo (Fabara), Escodines Altes, and Escodines Baixes (Mazaleón), towns that represent the first examples of stable settlements.

During the seventh century BC, hamlets or small settlements with a central street and rooms with rectangular floors that shared a common wall (Tossal del Moro, Tossal Redó, Sant Cristóbal, Piuró del Barranc Fondo, etc.) spread to the entire region. As regards construction, they were houses with walls erected on a stone foundation, sometimes integrated with a simple structure of orthostats. The burial pattern of these settlements was to have small areas of burial mounds, usually more than one for each centre, which seem to correspond to the existence of various kinship groups.

The Turó del Calvari building was constructed in the late Early Iron Age (580$550 \mathrm{BC}$ ), and seems to have responded to the need to carry the ideological strategies of a family or lineage that sought to legitimize their status through a discourse clearly 


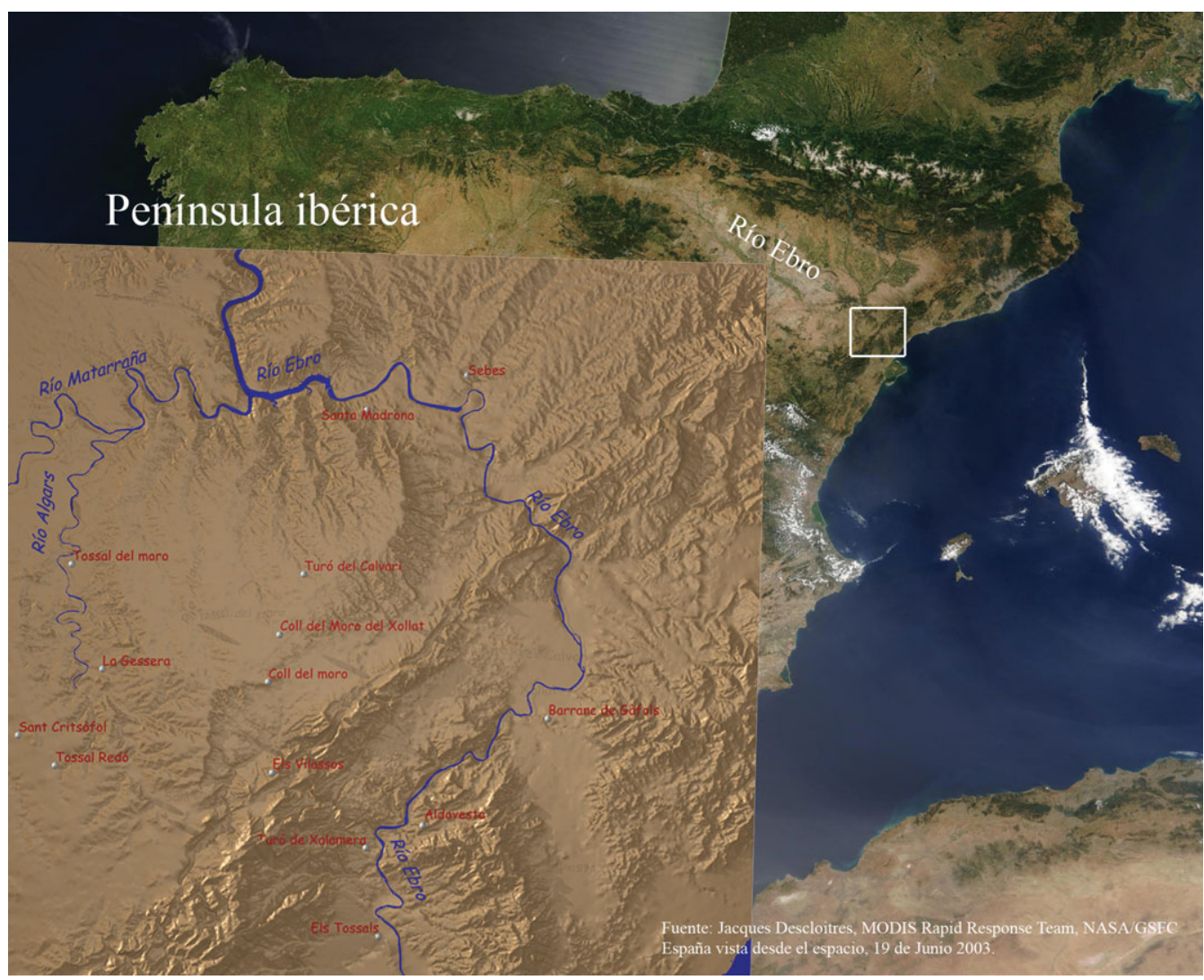

Figure 1. The situation and principal deposits of the territory of Terra Alta (Catalonia, Spain) during the Early Iron Age.

based on new parameters of social representation (Bea et al. 2002). In fact, the occupation of a facility of this kind in the period immediately prior to the introduction of Iberian culture probably represents a particular case - a paradigmatic example that serves to illustrate the diversity of ways in which people began to respond to social emergency. In this case, both the architectural aspects and the contextual evidence suggest an interpretative framework in which the 'ritualization' of certain practices served as a hub of convergence for tackling issues relating both to social change and to new cultural contacts that were taking place during the Early Iron Age in the Terra Alta and Matarrañ. Among these was the relationship with the Mediterranean world that involved the circulation of prestige goods such as personal ornaments (fabrics, glass paste, new bronze ornaments, iron ornaments) and especially wine. From this time onwards, social ceremonies included the ritual consumption of new products, as well as the use of certain special serving dishes for banquets (Sardà 2007; 2008; 2010). However, this change only affected some aspects of local tradition and was probably limited to a certain emerging social elite: the legitimacy of power was probably still based on kinship relationships (Rafel 2006: 142). It is precisely in the context of these processes that we must place the origin of new power and prestigious forms of expression, as represented by Turó del Calvari.

Turó del Calvari is not the only site where this Mediterranean inland-coastal relationship is verified. The Bajo Aragón tradition (albeit from the 7th century BC) is evident in the architecture and material of the tombs of the Coll del Moro necropolis (Gandesa), 
Figure 2. The site of Turo del Calvari before the excavation.

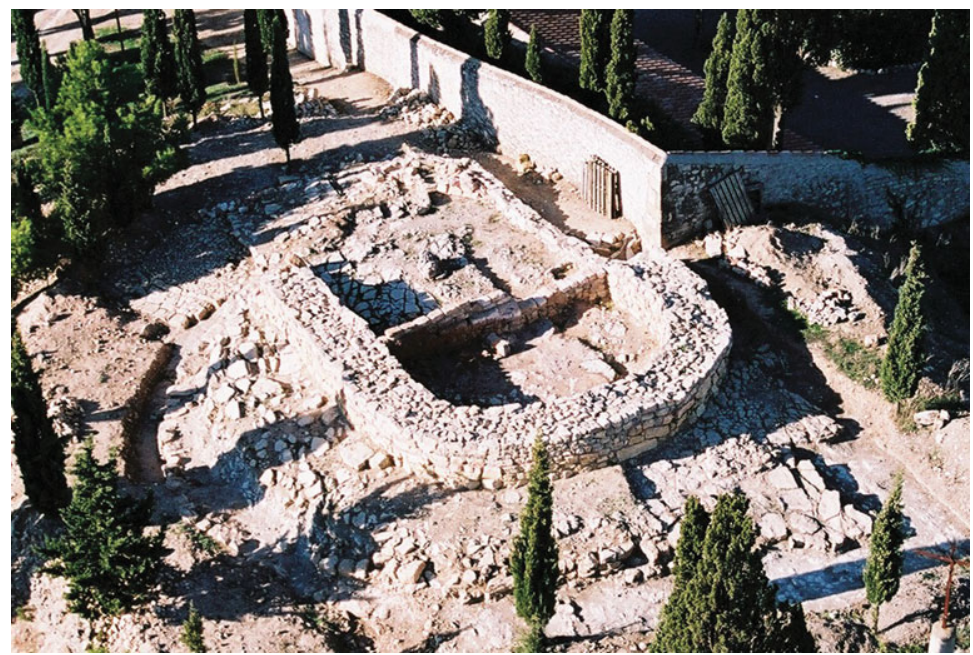

and it is not strange to find Phoenician pottery, made with a wheel, and other products with characteristics showing influences from the east. Given the evidence from the Coll del Moro necropolis and the Turó del Calvari building, we can safely say that the Terra Alta stayed connected to Mediterranean influences, and therefore acted as a transition area between the lower course of the Ebro and Bajo Aragón, while the control of this feedback was in native people's hands. However, we still cannot precisely determine what the counterpart in these exchanges might have been. Despite the Terra Alta and Aragon being territories with a high agricultural yield, the lack of archaeobotanical or palaeoconomical analysis means that we cannot clearly identify the goods that were exported at a time when trade was increasing (the impact of Phoenician trade, in particular, during the Early Iron Age is well documented).

From the mid-6th century BC onwards, a new phenomenon marks out the 'Iberization' process in this region. This is the appearance of tower-houses - authentic, isolated residences with an aristocratic character (Moret 2002). Yet these fortified residences, and the social system that supported them, only lasted a short time: they represented the zenith of a social model that would collapse during the second half of the 6th century $\mathrm{BC}$, when burial mounds disappeared and burials began to be placed in holes or loculi. The new world that would emerge in the 5th century BC coincided with the widespread deployment of Iberian cultural material (a generalization of Iberian ceramic and iron metallurgy), and had as its most relevant aspects the hierarchy of the population and proto-state organization.

\section{The Turó del Calvari building and the surrounding topography}

The Turó del Calvari was a rectangular turriform building with two rounded apsidal ends, set on a platform carved into the natural rock base. It had a double perimeter wall c. $1.50 \mathrm{~m}$ wide, and occupied a total area of $100 \mathrm{~m}^{2}$ and net floor area of $48.5 \mathrm{~m}^{2}$ per floor (see Fig. 2). Its unique location, on an isolated hill $450 \mathrm{~m}$ above mean sea level, means that it was prominently visible from, while also commanding a wide view of, the surrounding landscape (see Fig. 3). This allowed it to control the start of the Voravall ravine, through which a stream flows northwards into the Ebro river.

The construction of such an isolated and architecturally ostentatious enclosure where a number of clearly liturgical items were brought together (ceramic vessels for holding 


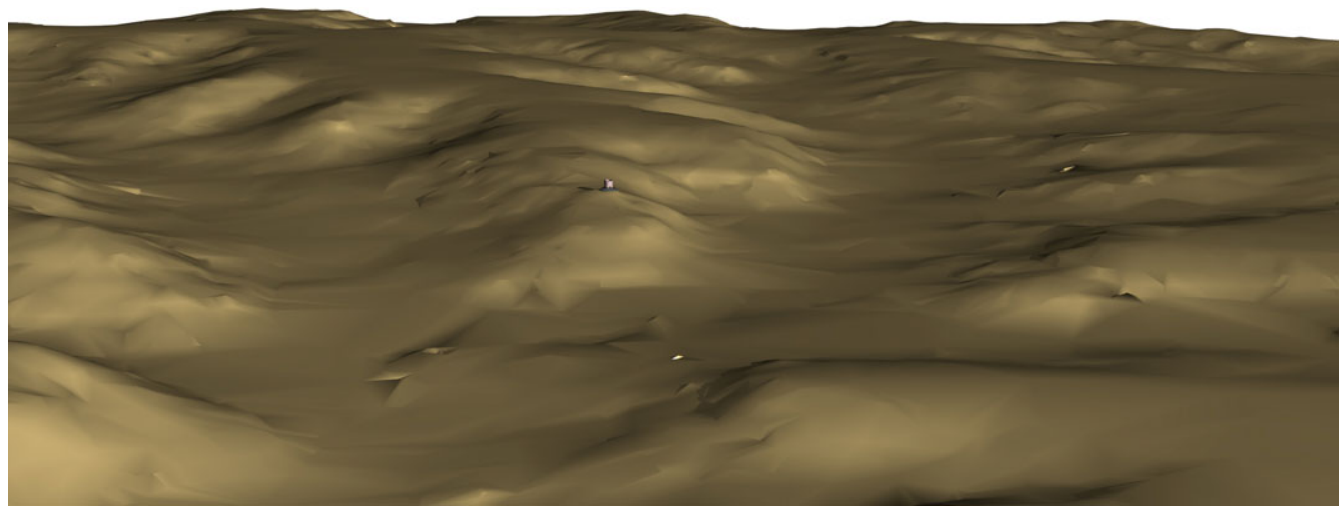

Figure 3. The Turo del Calvari in a Digital Terrain Model.

offerings, altar tables, crockery inspired by Phoenician examples, amphorae for wine, etc.) illustrates the existence of social differentiation: this centre had certain specialized functions that seem to be clearly linked to ritual management (Bea \& Diloli 2005) and possibly to astronomical cycles. The main axis of the building - it is orientated NNWcoincides remarkably well the orientation of the natural threshold on which it sits.

It could be argued that this topographic orientation was not coincidental but intentional, the intention being to integrate the building with the environment so that it went unnoticed. However, two things contradict this assertion. The first is its height: this, as estimated by the excavators, was about $10 \mathrm{~m}$, which would have made it a conspicuous sight from many kilometres around. (The thickness of the walls, c. $1.5 \mathrm{~m}$, is over twice what have been needed in order to raise them to the requisite height.) The second is that the building was erected on a circular podium around $2 \mathrm{~m}$ high, making it stand out even more. (It also protects the building by making it unapproachable apart from through the main door, which is located in the northernmost part of the main section of the building.)

\subsection{The design of the building: geometry and proportionality}

An accurate topographical survey of the building, complemented by a series of direct measurements within it, began to indicate the existence of a unit of measurement based upon the human foot. The variance in the values of the supposed unit, as deduced from the lengths of various key structural components of the building, is very small (a few millimetres), which allows us to conclude that a standard unit of measurement (one 'foot') equal to $0.295 \mathrm{~m}$, and defined with considerable precision, was used in the construction. The survey also revealed that the building had an exquisite geometrical design. Taken together, these indicate meticulous planning. It is unequivocal that the building was intended to be unique, and was designed for a special purpose.

The layout of the building is as simple as it is elegant (see Fig. 4). The floor area is determined by two circles tangential to each other, each 10 feet in radius and with its center on the main axis, plus the two external tangents perpendicular to their common tangent. This results in a building 40 feet long by 20 feet wide (about $12 \mathrm{~m}$ by $6 \mathrm{~m}$ ). The uniform wall thickness is 5 feet. This means that the outer boundary can be calculated by tracing two circles 15 feet in radius, whose centres coincide with those of the previous circles. The boundary itself is formed by half of each of these circles together with two external tangents. The building's outer dimensions are therefore 50 by 30 feet (about $15 \mathrm{~m}$ by $9 \mathrm{~m})$. 

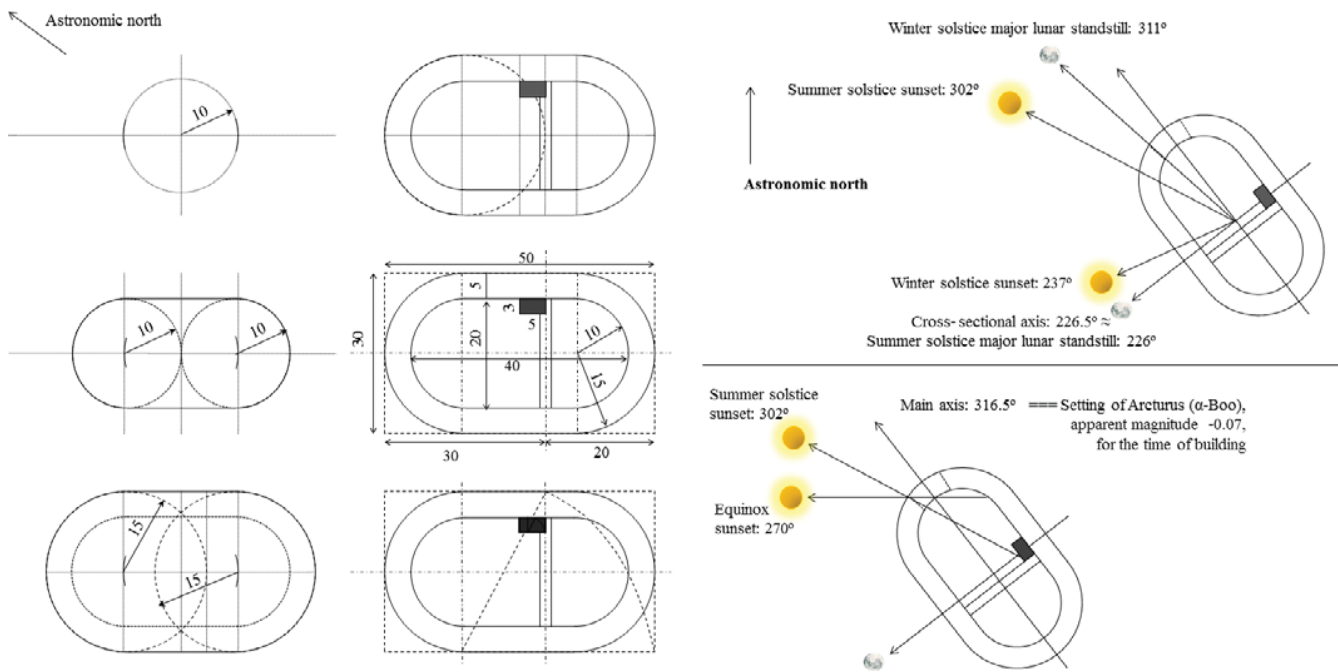

Figure 4. Geometry and astronomical orientations in the Turo del Calvari.

The building's interior is divided into two rooms by an adobe wall laid in stretcherbond style one span (equivalent to $\frac{3}{4}$ feet) thick. This is consistent with the standard size obtained for the adobe blocks used $(1.5 \times 1 \times 0.5$ span, equivalent to $0.34 \mathrm{~m} \times 0.22 \mathrm{~m} \times$ $0.135 \mathrm{~m}$ ) - built on a low stone base 1.5 feet in width. It seems that the wall did not rise beyond a metre and only served to raise the southern room's floor. This wall created a northern room 25 feet long and a southern room 15 feet long, both with a total usable width of 20 feet. The position of this division creates further geometrical symmetries (see Fig. 4). The ratio of the interior dimensions of the building as a whole are 2:1 $(40 \times 20$ feet), while those of the exterior dimensions are 5:3 $(50 \times 30$ feet $)$. A small altar situated in the corner of the northern wall and the retaining wall shares the latter ratio, scaled down exactly by a factor of ten (it measures $5 \times 3$ feet). The lengths of the two rooms, 25 feet and 15 feet respectively, also share this ratio, this time scaled down by a factor of 2. The radii of the circles used in the layout of the building are in the proportion of 3:2.

It is clear that both the dimensions of the building and the proportionality between them are unique. Measured in feet, all quantities (except for the width of the retaining wall) are multiples of 5 (the number of fingers on one hand). Additionally, the proportional relationships are simple and all achieved with the first four prime numbers, which are also the first four terms of the Fibonacci series (i.e. 1, 2, 3 and 5), thus obtaining the proportions $2: 1,3: 2$, and $5: 3$. It is noteworthy that the most important of these ratios appears to be 5:3, which appears in the outer dimensions of the whole building, the altar, and the relative lengths of the two rooms. It is also the first approximation to the golden ratio or golden section that can be obtained with a rational number. For this reason it has been used in many buildings for centuries, as it simplifies the process of laying out a building using ruler and compass (the method commonly employed by master builders).

It was Euclid who demonstrated the irrationality of the golden number, golden ratio and divine proportion, named $\phi$ in honour of Phidias, the architect of the Parthenon and whose sculptures are still considered the finest in antiquity, owing among other things to their proportions.

If we knew for certain the height of the building, we could also talk about its proportions, but clearly without this information we have to speculate. For the height to be in the golden ratio to one of the horizontal dimensions, it should measure either 18 feet 
$(5.4 \mathrm{~m})$ (in relation to the width) or 30 feet $(9 \mathrm{~m})$ (in relation to the length). (If it were the larger segment in the ratio then the height would have to be $50 \mathrm{ft}(15 \mathrm{~m})$ or 83.3 feet $(25 \mathrm{~m})$ respectively, which is very unlikely.) The excavation indicated the existence of two floors, by revealing the remains of a floor structure for the upper floor and the bases of columns that would probably have supported this structure. Given this, we can infer that the building was probably 18 feet, or perhaps 30 feet, in height.

\subsection{The astronomical orientation of the building}

The archaeological material found in the excavation of the building as well as its geometrical and architectural design are already sufficient to demonstrate the uniqueness of the construction. However, a third aspect supports and confirms that this building was very special. This is its astronomical connection. Our measurements showed that the main axis of the building is oriented at a true azimuth of $316.5^{\circ}$ (see Fig. 4). A topographic and photographic survey of the local horizon showed that no significant topographic features stand out in any direction-including in particular that of the axis of the building - so the building could not have been oriented topographically apart from as a result of the selection of the place, as discussed above.

The direction faced by the building is further north than that of summer solstice sunset (azimuth $302^{\circ}$ ). It is even further north than major lunar standstill moonset (azimuth $311^{\circ}$ ). The building's main axis actually faced the setting point of the star Arcturus, the third brightest star in the sky, in the 6th century BC.

Arcturus has been known and used since ancient times by many people and cultures. We have found three references to this star prior to the construction of the Turó del Calvari building. Homer mentions it in The Odyssey along with Orion and Ursa Major and Minor as providing the basic system of Phoenician navigation when the nymph Calypso indicated the way home to Odysseus. It is also mentioned by Hesiod in Works and Days, the heliacal rising and setting of Arcturus being an indicator of the dates for pruning and harvesting grapes and storing wine. (It is known that wine was introduced into all the Mediterranean countries by Phoenician traders.) Finally it is clearly linked to vine and wine in the ancient Attic legend of the Divine gift to man by Dionysius, son of Zeus and Semele (mortal daughter of Cadmus, a Phoenician legendary hero, founder of Thebes and introducer of the alphabet in Greece). Icarus, who was given the gift of the vine and wine, offered it to his neighbours who, after getting drunk, assassinated him. Maera, his dog, looked for Erigone, Icarius' daughter, who hanged herself after finding her father dead. Dionysius (or possibly Zeus) put them in the sky, Icarius as Boötes, Erigone as Virgo and Maera as Sirius or Procyon.

Another aspect of the Turó del Calvari building confirms the interest in the sun by the people who inhabited the Iberian Peninsula in the Early Iron Age (Pérez 2009; 2010). The orientation of the solitary entrance door, in the northerly part of the building, only allows the sun's rays to enter the interior between the spring equinox and the autumn equinox, and only close to sunset. At sunset around the summer solstice (but at no other time), the small stone altar becomes illuminated by the sun's rays (see Fig. 5). The sunlight never reaches the back of the building in which the smaller of the two rooms is located, this being elevated in the manner of a platform or a stage overlooking the larger room. We note that most of the Phoenician-Punic altars found in the Iberian Peninsula are oriented towards the rising, rather than the setting, sun at summer solstice (Escacena 2009).

At this point we should return to the discussion about the golden ratio 5:3 of the building. Aratus, in the 3rd century BC (probably while collecting information going back beyond the 1st millennium BC, and therefore prior to the time of our building), 


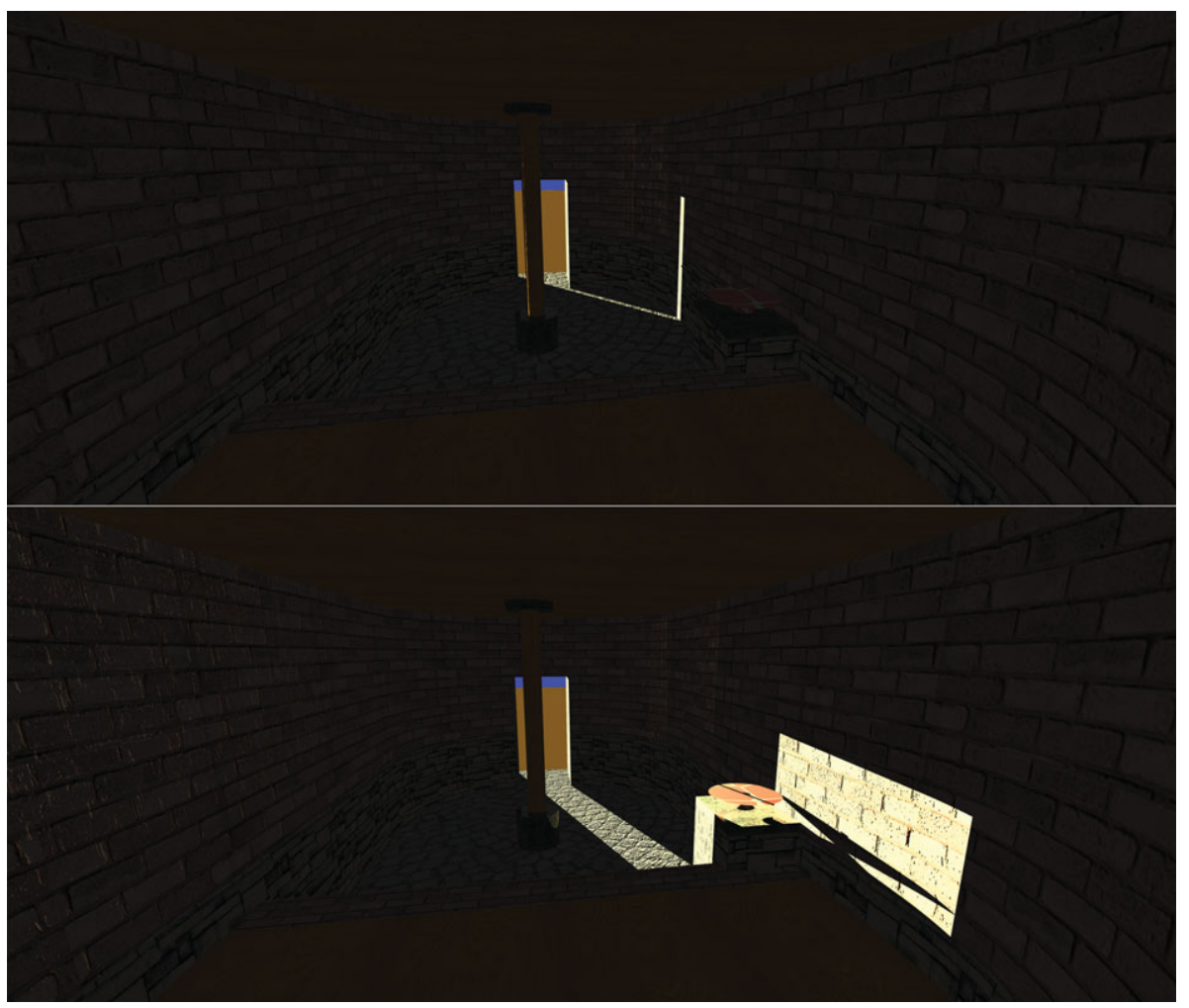

Figure 5. The sun entering the building at the equinoxes (upper picture) and summer solstice (lower picture), as viewed from the interior.

described the motion of the sun on the celestial sphere. In particular, he explained the seasons and the difference in the length of day and night that occurs through the year. Specifically, when the sun was placed in Cancer, it reached its maximum declination and summer began. "The circle [the Tropic of Cancer] was divided into eight parts, five of which occurred during daytime and the remaining three beneath the horizon" (Aratus, Phaenomena, 498). In other words, as the summer begins and the sun illuminates the inner altar, the ratio between the time that the sun spends above the horizon and below the horizon is also 5:3. Although it we can not say for certain that the builders of the Turó del Calvari possessed this knowledge, everything that we find in the building, both tangible and intangible, suggests this was very probably the case.

\section{Conclusions}

To sum up, the Turó del Calvari building was constructed during the Early Iron Age using techniques that were clearly indigenous, but with wider influences affecting both the building itself and much of the furniture and accessories that it contained. Its dimensions, along with the effort involved in raising it up upon a circular podium, made the building extremely impressive. In addition, its exquisite geometric design required a degree of planning quite unequalled in that time and place, as well as the surprising use of a standard unit of measurement that permitted all of its dimensions not only to be exact multiples of the said unit, but also multiples of 5 units. And finally, the proportions 
among its different dimensions made the building beautiful, although the precise reasons why this was the case still escape us.

If we consider the building as a whole, we can reject the idea that its orientation was random. The relation between Arcturus (or Boötes) and wine and the vine has been proven, although why this building should be so oriented is a non-trivial problem, as yet unanswered. It would not have been difficult to orient it towards sunset at the summer solstice, as is the case with many Punic-Phoenician altars, and there were no topographic obstructions. However, the building is constructed so that the light of the setting sun at the summer solstice is the protagonist as it illuminates the inner altar. The method used in the design and construction of the building, so as to include both the astral and the solar orientation, is just exquisite.

It would not be surprising to find that Greek culture and its associated knowledgesuch as the unit of measurement (attic foot), geometry and proportions, or the adoption of stories, legends and astronomical knowledge and other astronomy-related subjectswas disseminated on the coasts close to the mouth of the Ebro river and hence introduced into the Iberian peninsula by Greek travellers. The problem (and it is a delicate one) is that there is no archaeological evidence, nor any written or epigraphic sources, to support or confirm the presence of Greek sailors in the late 7th century BC on the shores of ancient Iberia near the mouth of the Ebro, nor in the Turó del Calvari. However, we cannot deny that this information, which was most likely present in the Phoenician world before the Greek, may well have arrived on the Catalan coast as a result of the Semitic traders who frequented it since at least the late 7 th century BC.

\section{References}

Bea, D., Diloli, J., \& Vilaseca, A. 2002, El Turó del Calvari (Vilalba dels Arcs, Terra Alta). Un recinte singular de la primera edat del ferro al curs inferior de l'Ebre. Paper presented at Ilercavònia 3. I Jornades d'Arqueologia. Ibers a l'Ebre. Recerca i interpretació, Tivissa, 23 i 24 de novembre de 2001 .

Bea, D. \& Diloli, J. 2005, Elements de representació durant la Primera Edat del Ferro al curs inferior de l'Ebre: el recinte del Turó del Calvari (Vilalba dels Arcs, Terra Alta). Revista d'Arqueologia de Ponent 15, 179-198.

Escacena, J. L. 2009, La Egersis de Melqart. Hipótesis sobre una teología solar cananea. Complutum 20(2), 95-120.

Moret, P. 2002, Tossal Montañés y La Gessera: ¿residencias aristocráticas del Ibérico Antiguo en la cuenca media del Matarraña? Paper presented at Ilercavònia 3. I Jornades d'Arqueologia. Ibers a l'Ebre. Recerca i interpretació, Tivissa, 23 i 24 de novembre de 2001.

Pérez, M. 2009, Astronomía y geometría en la Vettonia. Complutum 20(2), 141-164.

Pérez, M. 2010, Astronomía en los Castros Celtas de la Provincia de Ávila, Institución Gran Duque de Alba, Diputación Provincial de Ávila, Ávila.

Rafel, N. 2006, Sobre el canvi en la Protohistòria. Un cas d'estudi: la primera edat del ferro com a fonament del món ibèric al Matarranya i l'Algars. In M. C. Belarte \& J. Sanmartí (eds), "De les comunitats locals als estats arcaics: la formació de les societats complexes a la costa del Mediterrani occidental", Arqueomeditarrània 9, 135-144.

Sardà, S. 2007, Els Materials Ceràmics del Turó del Calvari (Vilalba dels Arcs, Terra Alta). Pràctiques de Consum Ritual a la Primera Meitat del Segle VI anE, Trabajo de Investigación, DEA, Universitat Rovira i Virgili, Tarragona.

Sardà, S. 2008, Servir el vino. Algunas observaciones sobre la adopción del oinochoe en el curso inferior del Ebro (s. VII-VI a.C.). Trabajos de Prehistoria 65(2), 95-115.

Sardà, S. 2010, Pràctiques de Consum Ritual al Curs Inferior de l'Ebre (s. VII-VI anE). Comensalitat, Ideologia $i$ Canvi Social, Doctoral thesis, Universitat Rovira i Virgili, Tarragona (www.tdx.cat/TDX-1013110-161238). 